\title{
Telaah Prinsip Good-Relationsip di Dalam Kepemimpinan dan Organisasi
}

\author{
Sonny Eli Zaluchu \\ Sekolah Tinggi Teologi Baptis Indonesia (STBI) Semarang \\ E-mail:sonnyzaluchu@stbi.ac.id \\ Mesirawati Waruwu \\ Sekolah Tinggi Teologi Baptis Indonesia (STBI) Semarang \\ E-mail:mesirawatiwaruwu@stbi.ac.id
}

\begin{abstract}
This research was conducted with a literature study that utilizes concepts, theories, and explanations from primary sources in books, journal papers, and other academic sources. The analysis presented descriptively to explore the principle of "good-relationship," a pattern of relationships created in leadership. The deepening of guides focuses on the efforts that need to be developed by a leader in influencing and functioning optimally for his followers to move together to achieve organizational goals. It can be concluded that transformative leadership is leadership that develops aspects of good-relationship through four main components, namely: leaders who get rid of the practice of fear, leaders who communicate effectively, leaders who are open or transparent, and leaders who are empathetic and listening. All of these components provide strong support for the formation of good-relationship patterns in any organization. Even though it can get affective commitment among followers, it was also found that these four components are an essential part of Christian leadership practice.
\end{abstract}

Keywords: Leadership; Good-Relationship; Organization; Communication; Organizational Commitment

\begin{abstract}
Abstrak
Penelitian ini dilakukan dengan studi literatur yang memanfaatkan konsep, teori dan penjelasan dari sumber sumber primer berupa buku, paper jurnal dan sumber akademik lainnya. Analisis disajikan secara secara deskriptif untuk mendalami prinsip 'goodrelationship' sebuah pola hubungan yang tercipta di dalam kepemimpinan. Pendalaman prinsip di fokuskan pada usaha yang perlu dikembangkan oleh seorang pemimpin dalam memengaruhi dan berfungsi maksimal terhadap para pengikutnya untuk bergerak bersamasama mewujudkan tujuan organisasi. Diperoleh kesimpulan bahwa kepemimpinan transformatif adalah kepemimpinan yang mengembangkan aspek good-relationship melalui empat komponen utama yakni: pemimpin yang menyingkirkan psikologi ketakutan, pemimpin yang berkomunikasi efektif, pemimpin yang bersifat terbuka atau transparan dan pemimpin yang bersifat empati dan mendengarkan. Seluruh komponen tersebut ternyata memberikan dukungan kuat bagi terbentuknya pola good-relationship di dalam organisasi manapun.
\end{abstract}


Bahkan melaluinya dapat diperoleh komitmen afektif di kalangan pengikut. Juga ditemukan bahwa keempat komponen ini merupakan bagian penting di dalam praktik kepemimpinan Kristen.

Kata-kata Kunci: Kepemimpinan; Hubungan Baik; Organisasi; Komunikasi; Komitmen Organisasi

\section{Pendahuluan}

Leading Matters adalah judul dari sebuah buku yang sangat kaya tentang kepemimpinan. Isinya memengaruhi banyak pemimpin di dunia karena penuh dengan prinsip-prinsip empirik sebagai hasil dari pengalaman kepemimpinan penulisnya. John L. Hennessy, penulis buku itu adalah seorang pionir pemimpin yang berhasil mengubah wajah organisasinya melesat sangat cepat akibat cara kepemimpinan yang menginspirasi banyak orang. Hennessy adalah presiden kesepuluh dari Stanford University yang bukan hanya membawa organisasinya berkembang pesat tetapi juga memproduksi banyak sekali pemimpin yang memengaruhi dunia. Perjalanan dan pengalaman kepemimpinan Hennessy ditulis di dalam buku tersebut. Dari semua uraiannya yang panjang lebar tentang keberhasilan seorang pemimpin, prinsip good-relationship sebuah konsep kunci kepemimpinan. Melalui good-relationship, seorang pemimpin mampu dipercaya, memimpin dengan melayani, berempati, memberi dorongan dan berkolaborasi dalam sebuah tim yang tangguh
(Hennessy, 2018, pp. 21-83). Hasilnya seluruh mesin organisasi bergerak bersama-sama untuk mencapai misi dan visi.

Temuan penelitian Aini dkk menguatkan pengalaman Hennessy. Dalam penelitian tentang hubungan atasanbawahan, Aini dkk menyimpulkan bahwa terdapat hubungan yang positif dan siginifikan antara interaksi atasan-bawahan yang baik dan berkualitas dengan organizational citizenship behavior. Tidak mengherankan, Stanford University mengalami kemajuan yang sangat luar biasa di masa kepemimpinan Hennessy. Apalagi menurut temuan Aini dkk menjelaskan asumsi dasar bahwa faktor organisasional yang berkaitan dengan organizational citizenship behavior adalah quality of work life. Karyawan yang mengalami dan merasakan peningkatan di dalam quality of work life didorong oleh munculnya organizational citizenship behavior. Semua kembali kepada faktor $\mathrm{X}$ yakni kemampuan pemimpin untuk membangun relasi yang baik dengan pengikutnya (Aini et al., 2014). Bahkan di dalam penelitian Rosiani terbukti bahwa 
prestasi karyawan didongkrak oleh cara bawahan mempersepsikan pemimpin. Persepsi ini ditentukan oleh cara pemimpin membangun good-relationship pada orang-orang yang berada di dalam lingkup pengaruhnya (Rosiana, 2015).

Berdasarkan hal tersebut di atas terlihat bahwa kehadiran pemimpin dengan konsep-konsep priyayi, sebagaimana ditampilkan oleh para pemimpin Jawa tempo dulu dalam tulisan Widyomartono dianggap tidak lagi selaras dengan perkembangan zaman (Wiryomartono, 2020). Menurutnya, priyayi pada masa lampu mempertahankan elitisme dan membangun batas-batas dengan orangorang yang berada di dalam pengaruh kekuasaannya. Hal ini dapat dimaklumi bahwa konsep kepemimpinan semacam ini adalah produk budaya yang menekankan elitisme pemimpin dan karismatisme (House \& Howell, 1992). Berbeda dengan pengalaman Hannessy, batas-batas kekuasaan pemimpin tradisional digeser ke arah egaliter. Pemimpin hadir di tengahtengah pengikutnya untuk memengaruhi (Zaluchu, 2020b) dan secara bersama-sama bekerja membangun sebuah team work untuk mencapai tujuan (Maxwell, 2012).

Berdasarkan uraian tersebut di atas menarik untuk melakukan pengkajian terhadap faktor-faktor kunci yang menentukan good-relationship antara pemimpin dengan bawahan, yang tidak hanya terbatas pada konsepsi tetapi merupakan faktor yang bersifat praktik dan terukur. Penelitian di dalam paper ini diarahkan untuk mengidentifikasi faktorfaktor penentu di dalam good-relationship untuk pengembangan kepemimpinan dimanapun dipraktekkan.

\section{Metode Penelitian}

Penelitian ini dilakukan dengan kajian pustaka (literature review) yang bertumpu sepenuhnya pada buku-buku kepemimpinan dan laporan penelitian luaran jurnal mengenai topik-topik yang berkaitan dengan paper penelitian ini. Analisis difokuskan pada sejumlah kriteria yang menjadi bagian dari konsep utama topik penelitian good-relationship. Hasil penelitian disajikan secara deskriptif mengikuti model laporan penelitian seperti diusulkan oleh Baker (2016) dan Zaluchu (2020a). Pembahasan pertama-tama adalah pemaparan deskriptif tentang konsep goodrelationship sebagai variabel utama lalu dilanjutkan dengan analisis teoritis terhadap sejumlah konsep kunci yang menjadi penyusun variabel utama penelitian. Desain yang diusulkan mengikuti pola hubungan sebagaimana terbentuknya endogenous-eksogenous variabel. Good-relationship menjadi modelnya sehingga disebut sebagai variabel endogen. Sementara sejumlah variabel eksogen sebagai penyusun model 
di dalam paper ini adalah komunikasi efektif, keterbukaan atau transparansi dan kemampuan mendengar. Model tidak diuji secara statistik dan hanya meminjam istilah. Sepenuhnya pembahasan di dalam paper ini adalah konseptual dan teoritik.

\section{Pembahasan dan Hasil}

\section{Good-Relationship}

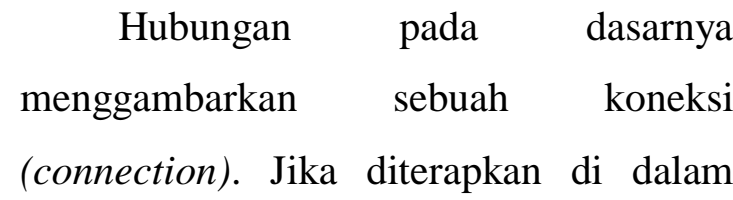
interaksi sosial maka hal tersebut dapat berarti rangkaian atau situasi saling bersambung antar-manusia. Contohnya, koneksi persahabatan, hubungan antar lawan jenis, kekerabatan, dan koneksi di dalam lingkungan sosial. Itulah sebabnya dimengerti bahwa konsep kunci dari sebuah hubungan adalah interaksi interpersonal. Melaluinya komunikasi berlangsung, kesepahaman tercipta dan kebudayaan terbentuk. Akan tetapi, jika dilihat dari arahnya, sebuah hubungan dapat dilihat dari dua kutub yang saling berlawanan. Sebuah hubungan dikatakan positif ketika hubungan tersebut bermanfaat dan pihak-pihak yang terlibat di dalamnya saling menerima keuntungan. Sebaliknya, sebuah hubungan negatif akan terbentuk ketika jalinan yang ada mengarah pada keuntungan sepihak, saling memanfaatkan dan pada akhirnya bertujuan meruntuhkan.
Seorang pemimpin yang berhasil membangun relationship dengan bawahannya akan menciptakan sebuah kelekatan emosional yang membangkitkan komitmen dan mewujudkan terjadinya keinginan untuk mewujudkan kebutuhan psikologis. Bawahan ingin berada dekat pemimpinnya dan dengan rela menaklukan diri untuk dipimpin. Sebaliknya, pemimpin memiliki kedekatan dengan bawahannya dan menyadari bahwa orang-orang yang dipimpinnya itu merupakan aset terbesar kepemimpinannya. Menurut pendekatan teori psikologi Sternberg seperti dikutip oleh Abdiani \& Ahmadi, akan terlihat ciriciri tertentu di dalam sebuah hubungan yang berjalan baik dan berhasil. Pertama, terciptanya kedekatan (intimacy). Kedekatan yang dimaksud adalah rasa untuk menjadi bagian penting satu dengan lainnya yang terus meningkat intensitasnya seiring lancarnya komunikasi. Kedua adalah hasrat (passion). Di dalamnya terlibat emosi dan kepuasan psikologis yang memberikan efek, antara lain keinginan untuk berkorban, memberi yang terbaik dan penaklukan diri serta kenyamanan untuk bekerja/dipimpin. Sedangkan yang ketiga adalah komitmen. Di dalam tahap ini, terbentuk gaya sentrifugal dimana semua orang yang berada di dalam kepemimpinan menyatu dan terikat di dalam rasa memiliki yang 
kuat, baik secara individual maupun secara organisasional.

Berpijak pada kepemimpinan yang dirumuskan Maxwell sebagai fungsi pengaruh, terlihat bahwa relationship yang baik di dalam kepemimpinan akan menjadi katalis bagi terbentuknya pengaruh yang kuat di dalam kepemimpinan itu sendiri. Kemana pemimpin pergi, ke sanalah orang-orang akan mengikuti dan melakukannya dengan rela.Kepemimpinan adalah tindakan pemimpin yang mendorong pengikut untuk bertindak mencapai tujuan tertentu yang mewakili nilai dan motivasi (keinginan dan kebutuhan), aspirasi dan harapan, baik dari pemimpin maupun pengikut (Burns, 2010, p. 19). Semua tujuan tersebut hanya akan tercapai ketika terbentuknya goodrelationship yang hasil akhirnya adalah komitmen.

Teori organisasi memperkenalkan tiga jenis komitmen yang terbentuk di kalangan bawahan sebagaimana dikemukakan oleh Allen \& Meyer (1990). Ketiga bentuk komitmen itu adalah komitmen afektif (affective commitment), komitmen kontinuans (continuance commitment) dan komitmen normatif (normative commitment). Komitmen normatif adalah komitmen yang terbentuk ketika seseorang memiliki pengalaman sosialisasi di dalam organisasi. Wujudnya terlihat dari adanya sikap memberikan balasan karena jasa yang telah diberikan organisasi melalui pemimpin. Individu dengan komitmen normatif yang tinggi akan cenderung bertahan dalam organisasi karena merasa dirinya harus berada dalam organisasi tersebut. Dalam komitmen ini terdapat sejumlah faktor yang membuat individu mengembangkan perasaan terikat pada organisasi seperti ikatan moral, ikatan keagamaan, ikatan sosial, ikatan sejarah, sentimen denominasional atau ikatan kekeluargaan dan juga ikatan kepemimpinan. Ikatan sebagai ekspresi jasa juga termasuk di dalamnya. Sedangkan komitmen kontinuans adalah komitmen yang terbentuk karena kebutuhan. Komitmen ini mengarah pada kesadaran individu bahwa dirinya akan mengalami kerugian besar jika harus meninggalkan organisasi dan pemimpinnya. Komitmen ini tidak dapat memicu seseorang untuk memberikan kontribusi terbaik bagi organisasi, baik dalam hal performa, kehadiran dan rasa memiliki, sebagaimana orang dengan komitmen afektif. Apabila organisasi mengalami konflik, individu dengan komitmen kontinuans cenderung pasif dan tidak ambil bagian untuk mencari solusi selama kepentingan dan fasilitas yang dinikmatinya tidak terancam.

Ujung dari good-relationship bukan komitmen normatif, terlebih komitmen kontinuans. Jenis komitmen yang menjadi 
hasil dari sebuah hubungan baik adalah komitmen afektif. Individu yang memiliki komitmen afektif, memiliki kecenderungan bertahan pada pekerjaannya karena kerelaan atau keinginannya sendiri. Organisasi dianggap sebagai bagian dari keluarga dimana individu telah memiliki kenyamanan di dalamnya. Ditinjau dari sisi organisasi, komitmen ini terbentuk karena iklim kerja yang baik, hubungan atasan-bawahan yang komunikatif dan demokratis serta kemampuan organisasi menciptakan kenyamanan bekerja. Totalitas adalah salah satu hasil dari komitmen afektif. Terhadap apapun yang menjadi tanggung jawabnya terhadap organisasi, individu memperlihatkan hasil yang maksimal dan tuntas dan terbaik (Meyer et al., 2002).

Dengan demikian dapat disimpulkan bahwa sebuah kepemimpinan akan berfungsi dengan baik ketika pemimpin di dalam kepemimpinan itu mampu menciptakan dan membangun hubungan baik kepada orang-orang yang dipimpinnya.

\section{Komponen Utama}

Sudut pandang kepemimpinan menghasilkan sejumlah pendekatan bagaimana menampilkan tipikal pemimpin yang memenuhi standar good-relationship. Gambar berikut ini menampilkan sejumlah pendekatan yang diperlukan. Keempatnya saling berinteraksi satu sama lain dan berjalan secara simultan di dalam praktik kepemimpinan

\section{Gambar Matrik Faktor Kepemimpinan}

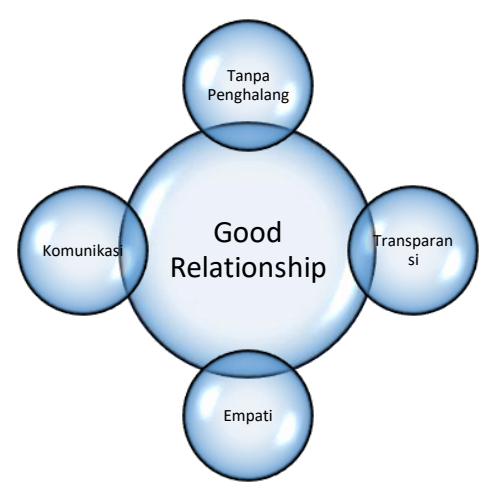

Good-Relationship

\section{Pemimpin yang Menyingkirkan Psikologi \\ Ketakutan}

Pemimpin tradisional biasanya membangun pengaruh melalui sejumlah usaha yang mengarah pada barrier offear. Akan tetapi di masa kini, model kepemimpinan seperti itu tidak relevan lagi. Pemimpin justru harus berada di tengah-tengah pengikutnya, bukan berjarak dan membangun ketakutan. Sebuah barrier of fear adalah tindakan membangun pengaruh dengan menciptakan situasi psikologis tertentu sehingga pengikut merasa takut kepada pemimpinnya, takut menghadap pemimpin, takut berbicara kepada pemimpinnya dan sebagainya. Jika hal demikian yang terjadi, maka goodrelationship menjadi sebuah kemustahilan. Pemimpin yang seperti ini akan dijauhi, 
bukan karena segan tetapi demi menghindari masalah (Sanders, 2017, pp. 15-24).

Sebaliknya, pemimpin yang membangun persahabatan dan keakraban dengan pengikutnya akan mampu dengan mudah membangun pengaruh dan membentuk orang lain. Dengan cara ini, pemimpin dapat mengelola emosi pengikutnya dan memotivasi secara langsung. Komunikasi yang terjadi bersifat dua arah dan langsung (face to face). Hasilnya adalah terbentuknya komunikasi efektif antara pemimpin dan pengikut. Menurut Kartajaya, runtuhnya penghalang psikologis di dalam kepemimpinan akan menghasilkan pengaruh yang kuat, melekat dan mampu menggerakkan pengikut di dalam skala besar (Kartajaya \& Ridwansyah, 2015, pp. 109-110).

\section{Pemimpin yang Berkomunikasi Efektif}

Berpijak pada definisi komunikasi, dapat disimpulkan bahwa di dalam sebuah komunikasi tercapai adanya kesepahaman dan saling pengertian. Etimologi 'common' di dalam kata komunikasi berarti bersamasama, sehingga dapat dikatakan bahwa komunikasi adalah proses menyamakan presepsi, pikiran dan perasaan antara komunikator dengan komunikan (Waruwu, 2020, pp. 157-169). Dengan demikian komunikasi sangat penting dalam penyampaian sesuatu melebihi berbagi bentuk informasi yang disalurkan dengan cara lain. Meminjam konsep kepemimpinan guru di dalam kelas sebagaimana hasil penelitian Wisman (2017) terdapat tiga bentuk komunikasi efektif yang dapat dikembangkan dan dipraktikkan pemimpin dalam rangka good-relationship. Ketiganya adalah pertama, komunikasi informative (informative communiation). Komunikasi ini menyampaikan pesan agar pengikut tidak ketinggalan informasi dan mengetahui informasi yang menunjang pekerjaan atau tanggung-jawabnya. Kedua, komunikasi persuasif (persuasive communication). Bentuk komunikasi ini memberikan informasi untuk memengaruhi pandangan, merubah sikap atau perilaku pengikut sebagai hasil dari kesadaran internalnya. Ketiga adalah komunikasi instruktif/ koersif (instructive/ coercive communication). Komunikasi jenis ini memiliki tekanan tertentu seperti ancaman, peringatan (warning) agar pengikut melakukan sesuatu dengan benar (tanpa salah), tepat waktu, sesuai prosedur. Pelanggaran atas informasi akan menghasilkan konsekuensi yang merugikan.

Melalui kombinasi ketiga bentuk komunikasi efektif ini tercipta proses interaksi yang menopang kinerja organisasi (Dirham, 2019). Tanpa adanya komunikasi, tujuan organisasi akan 
menjadi sulit tercapai karena tidak pernah bisa disosialisasikan bolak balik antara pemimpin dan pengikut. Oleh karena itu, Wijaya mengingatkan bahwa tersendatnya komunikasi akan berdampak langsung pada hadirnya gangguan irama dan kelancaran kerja (Agus Wijaya et al., 2015, p. 12). Gangguan ini bermuara pada terhambatnya tujuan organisasi. Karena fungsi pemimpin adalah sosok yang mempengaruhi maka dalam hal ini, beban berada di pundaknya sebagai seorang komunikator kepada pengikutnya (Yudiaatmaja, 2013).

\section{Pemimpin yang Bersifat Terbuka atau Transparan}

Transparansi telah menjadi elemen penting dalam sebuah hubungan baik. Tetapi di sisi lain, transparansi sejatinya adalah hasil dari good-relationship. Dengan adanya sikap terbuka, maka segala interaksi di dalam kepemimpinan menjadi transparan. Pengikut merasa penting karena menerima informasi dari tangan pertama (pemimpin) dan pemimpin dapat menerima input dari pengikutnya akibat share of idea yang transparan tersebut. Hal ini sangat baik terkhusus menyangkut keputusan-keputusan yang melibatkan stakeholder di dalam lingkup kepemimpinan. Pengikut akan membentuk sebuah inner values bahwa kedudukan mereka di dalam organisasi bukan objek atau pelengkap melainkan partner. Situasi ini menguntungkan karena dapat mempercepat terbentuknya komitmen afektif di kalangan pengikut.

Menurut Weningtyas, keterbukaan merupakan aspek penting di dalam komunikasi. Terlebih di dalam bentuk komunikasi interpersonal, keterbukaan menjadi indikator yang menjamin adanya respon positif dan kesetaraan (Weningtyas \& Ni, 2012). Temuan Rini dkk menyangkut keterbukaan di dalam keluarga dapat dijadikan pegangan. Keterbukaan ternyata berpengaruh di dalam kebahagiaan, kepuasan dan kepercayaan di dalam keluarga (Rini \& Retnaningsih, 2008). Hal yang sama dapat terjadi di dalam kepemimpinan. Secara psikologi, keterbukaan dapat berdampak positif dengan terbentuknya kepuasan dan kepercayaan yang kuat di kalangan pengikut kepada pemimpinnya. Seperti penelitian yang juga dilakukan oleh Setiaman dkk, bahwa keterbukaan informasi kepada publik akan menjamin kuatnya azas good governance dan menguatnya tingkat kepercayaan publik terhadap pemerintah (Setiaman et al., 2013). Itulah sebabnya dikatakan sebuah pemerintahan yang baik adalah pemerintahan yang menjamin akuntabilitasnya dengan transparansi (Krina, 2003). Konsep serupa dapat dibawa ke dalam prinsip kepemimpinan. 
Pemimpin yang transparan akan meningkatkan akuntabilitasnya dan berdampak pada naiknya partisipasi pengikutnya.

Tidak ada jaminan bahwa seorang pemimpin akan sempurna di dalam menjalani tugasnya memengaruhi dan memimpin orang lain. Melalui keterbukaan, pengikut dapat dengan mudah melakukan kontrol, memberi kritik dan terlebih menghadirkan umpan balik kepada pemimpinnya.

\section{Pemimpin yang Bisa Empati dan}

\section{Mendengarkan}

Mendengar selalu berjalan paralel dengan sikap empati. Seorang pemimpin tidak akan mampu membangun empati di dalam dirinya tanpa belajar mendengar. Harus disadari bahwa komunikasi efektif hanya dimungkinkan terjadi ketika komunikasi tidak berlangsung top down sebagaimana model kepemimpinan tradisional. Kepemimpinan yang benar justru harus mendukung praktik komunikasi dua arah, tidak melulu searah dari pemimpin kepada pengikut. Komunikasi harus dibentuk dari bawah ke atas (bottom-up). Untuk mewujudkannya, pemimpin dituntut untuk membuka keran komunikasi dari bawah dan perlu belajar mendengarkan isi hati pengikutnya.

Pemimpin-pendengar sangat esensial dalam sebuah organisasi. Dengan mendengarkan maka pemimpin mengembangkan di dalam dirinya sikap menghargai dan empati terhadap orang lain. Hal ini bukanlah perkara yang mudah dilakukan, terlebih jika berkaitan dengan kapasitas dan level otoritas. Untuk dapat menerima dan mendengar orang lain, seorang pemimpin membutuhkan kerendahan hati. Hasil dari sebuah kepemimpinan seperti ini adalah konsistensi hubungan yang bersifat mutualisme dalam jangka waktu yang lama.

Mendengar adalah sebuah keterampilan yang perlu dikembangkan. Banyak pemimpin melatih diri di dalam berbagai teknik public speaking tetapi gagal mengembangkan keterampilan untuk mendengarkan orang lain. Penting dipahami bahwa justru dengan mendengar, informasi akan masuk dari segala arah. Angela melakukan penelitian tentang topik ini di kalangan dokter saat berinteraksi dengan pasiennya. Menurutnya ada lima kapasitas mendengarkan yang perlu dikembangkan yakni mendengarkan dengan rasa ingin tahu, mendengarkan reflektif, mendengarkan empatik, mendengarkan perbedaan dan mendengarkan dalam diam (Buffington et al., 2016).

Informasi adalah sesuatu yang sangat esensial (Tyas et al., 2016). Pemimpin yang hanya memiliki sedikit konten 
informasi akan kehilangan horizon di dalam setiap keputusan yang dihasilkannya. Prediksi-prediksinya akan tertinggal karena didahului oleh orang lain. Oleh sebab itu, di dalam sebuah goodrelationship keberhasilan dalam sebuah organisasi ikut ditentukan oleh kemampuan dan kesediaan pemimpin untuk mendengar, menyerap, menganalisis, dan mengevaluasi semua input informasi dari pengikutnya. Keterampilan mendengar yang dulunya dianggap sebagai soft skill bagi pemimpin, kini diakui sebagai sebuah keterampilan esensial.

\section{Tantangan dalam Kepemimpinan Kristen}

Good-relationship adalah model kepemimpinan Yesus kepada muridmurid-Nya. Di dalam riwayat kepemimpinan-Nya selama 3 tahun, Yesus selalu memperlihatkan jati diri pemimpin yang berbicara dan mendengar. Dialog hampir selalu mewarnai kepemimpinan Yesus dan di dalam seluruh ajaran-Nya. Yesus tidak hanya berbicara tetapi Dia juga mendengar dan transparan di dalam bersikap. Segala hal yang diajarkan-Nya gamblang dan terang benderang. Praktik komunikasi efektif sangat terlihat di dalam gaya kepemimpinan-Nya. Dapat disimpulkan di sini bahwa model kepemimpinan good-relationship tersebut ada di dalam diri Yesus.

Oleh karena itu menurut Henson, setiap generasi pemimpin Kristen dipanggil untuk mengikuti model yang praktikkan oleh Yesus Kristus. Itulah sebabnya Paulus mengingatkan kepada jemaat di Korintus untuk, "Jadilah pengikutku, sama seperti aku juga menjadi pengikut Kristus." (1 Korintus 11:1). Yesus merupakan teladan kepemimpinan yang tepat (Henson, 2020). Persoalannya, inspirasi tentang kepemimpinan tidak hanya lahir dari konsep-konsep Alkitab. Berkembangnya ilmu manajemen, organisasi dan kepemimpinan telah menghasilkan munculnya berbagai konsep kepemimpinan dari berbagai pendekatan. Oleh karena itu, untuk mempertahankan kepemimpinan Kristen dan prinsipprinsipnya, perlu dilakukan penggalianpenggalian terbaru dari prinsip-prinsip Alkitabiah. Konsep yang perlu disodorkan kepada dunia tidak melulu kepemimpinan hamba seperti pernah dikonsepkan oleh Greenleaf (Cogliser, 2005).

Di masa disrupsi dan perkembangan teknologi yang begitu pesat, kehidupan dan alat-alat penunjang spiritualitas manusia mengalami perubahan yang radikal. Orang membaca Alkitab tidak lagi dari buku tetapi lewat smartphone. Ibadah tidak lagi harus di gedung gereja karena dapat diikuti secara online. Teknologi telah berkembang sangat 
pesat tetapi menyodorkan konsep klasik kepemimpinan hamba di tengah serbuan robot, mesin dan otomatisasi industri (Setiawan, 2017) telah membuat pandangan tentang kepemimpinan Kristen menjadi konsep ortodoksi. Pertanyaannya adalah apa yang mau dilayani ketika robot dan mesin telah mengambil alih pekerjaan manusia? (Frank et al., 2018).

Konsep kepemimpinan Kristen mau tidak mau mengalami pergeseran. Meskipun tujuannya akhirnya adalah pelayanan sebagaimana Yesus praktikkan, konsep-konsep terbaru harus dihadirkan sebagai jawaban terhadap perubahan zaman. Good-relationship adalah salah satu sodoran konsep tersebut. Hal ini dimungkinkan karena konsep ini bukan metode atau matriks dengan pola baku. Good-relationship adalah inner values yang perlu dimiliki dan dikembangkan oleh setiap pemimpin Kristen manapun yang dapat terimplementasi di dalam berbagai bidang, model dan metode. Konsep kepemimpinan Kristen dapat saja berubah dan menjadi tidak relevan, tetapi nilai-nilainya akan terus bertahan.

\section{Kesimpulan}

Good-relationship di dalam kepemimpinan dan organisasi adalah sebuah kemutlakan. Karena hal ini merupakan sebuah aspek perilaku maka pengembangannya sangat bergantung pada kemauan pemimpin untuk melatih dan mengembangkan keterampilannya membangun hubungan dengan orang-orang yang ada di sekitarnya. Selain menjadi sebuah keterampilan, good-relasionship adalah sebuah style kepemimpinan. Meskipun definisinya sama, yang membedakan satu pemimpin dengan pemimpin lainnya adalah gaya kepemimpinan. Ada pemimpin yang mengembangkan gaya otoriter dan kekuasaan, tetapi ada pula pemimpin yang mengembangkan gaya komunikatif dan pelayanan. Semua kembali pada pribadi pemimpin itu sendiri. Hasil penelitian memperlihatkan pengembangan gaya kepemimpinan komunikatif akan membawa keuntungan bagi organisasi dan pencapaian visi-misi pemimpin. Zaman yang berubah dan penuh informasi ini harus diikuti oleh style kepemimpinan yang relevan. Model tirani dan pendekatan kekuasaan hanya akan membuat pengikut gagal membangun komitmen afektif-nya. Pemimpin dengan model seperti ini akan ditinggalkan. Sebaliknya, pemimpin yang membangun hubungan dan membuka diri terhadap pengikutnya, akan dengan cepat diikuti dan dijadikan panutan. Orang-orang beranggapan bahwa pemimpin demikian akan membawa pengikutnya mengalami transformasi dan mempersiapkan pengikut menjadi next leader. Good-relationship adalah model kepemimpinan yang 
menembus banyak hambatan seperti selama ini terdapat di dalam kepemimpinan.

\section{Daftar Pustaka}

Agus Wijaya, Purnomolastu, N., \&

Tjahjoanggoro, A. J. (2015).

Kepemimpinan Berkarakter: Untuk

Para Pemimpin dan Calon Pemimpin

Masa Depan Indonesia. Brilian.

Aini, F. A., Hardjajani, T., \& Priyatama,

A. N. (2014). HUBUNGAN

ANTARA KUALITAS INTERAKSI

ATASAN-BAWAHAN DAN

QUALITY OF WORK LIFE

DENGAN ORGANIZATIONAL

CITIZENSHIP BEHAVIOR

KARYAWAN PT. AIR MANCUR

PALUR KARANGANYAR.

Wacana Jurnal Psikologi, 6(11), 55-

72.

https://doi.org/https://doi.org/10.1305

7/wacana.v6i1.4

Allen, N. J., \& Meyer, J. P. (1990). The

measurement and antecedents of

affective, continuance and normative

commitment to the organization.

Journal of Occupational Psychology, 63(1), 1-18.

https://doi.org/10.1111/j.2044-

8325.1990.tb00506.x

Baker, J. D. (2016). The Purpose, Process, and Methods of Writing a Literature Review. AORN Journal, 103(3),
265-269.

https://doi.org/10.1016/j.aorn.2016.0

1.016

Buffington, A., Wenner, P., Brandenburg, D., Berge, J., Sherman, M., \& Danner, C. (2016). The Art of Listening. Minnesota Medicine. https://doi.org/10.7748/nop.21.7.10.s 9

Burns, J. M. (2010). Leadership. Harper \& Row Publisher.

Cogliser, C. C. (2005). Servant Leadership : the Leadership Theory. Leadership Quarterly, 1-17. https://doi.org/10.1016/j.leaque.2004. 09.004

Dirham, D. (2019). Gaya Kepemimpinan Yang Efektif. Dinamis: Journal of Islamic Management and ..., 2(1). https://doi.org/10.24256/dinamis.v2i 1.994

Frank, M., Roehirg, P., \& Pring, D. Ben. (2018). Apa yang harus dilakukan Ketika Mesin Melakukan Semuanya. Elek Media Komputindo.

Hennessy, J. L. (2018). Leadership Matters - Lessons from My Journey. Stanford University Press.

Henson, J. D. (2020). Christian Leaders as Imitators: Jesus as the Ultimate Example of Leadership. Modern Metaphors of Christian Leadership, 289-308.

https://doi.org/10.1007/978-3-030- 
36580-6_17

House, R. J., \& Howell, J. M. (1992).

Personality and charismatic

leadership. The Leadership

Quarterly, 3(2), 81-108.

https://doi.org/10.1016/1048-

9843(92)90028-E

Kartajaya, H., \& Ridwansyah, A. (2015).

WOW Leadership - Kepemimpinan

yang Menggerakkan Pikiran,

Perasaan serta Spirit Kemanusiaan

(2nd ed.). Gramedia Pustaka Utama.

Krina, L. L. (2003). Indikator \& Alat

Ukur Prinsip Akuntabilitas,

Transparansi \& Partisipasi.

Sekretariat Good Public Governance

BPPN, 1-25.

Maxwell, J. C. (2012). The 21

Indispensable Qualities of a Leader.

21 Indispensable Qualities of a

Leader - Business Book Summaries.

Meyer, J. P., Stanley, D. J., Herscovitch,

L., \& Topolnytsky, L. (2002).

Affective, continuance, and

normative commitment to the

organization: A meta-analysis of

antecedents, correlates, and

consequences. Journal of Vocational

Behavior, 61(1), 20-52.

https://doi.org/10.1006/jvbe.2001.18

42

Rini, Q., \& Retnaningsih, R. (2008).

Keterbukaan Diri Dan Kepuasan

Perkawinan Pada Pria Dewasa Awal.
Jurnal Ilmiah Psikologi Gunadarma, I(2), 152-157.

Rosiana, D. (2015). Pengaruh Persepsi

Gaya Kepemimpinan Atasan

Terhadap Motivasi Berprestasi

Bawahan ( Studi Pada Karyawan Bca

Kantor Cabang Alam Sutera).

Fakultas Psikologi, 13(2), 38-46.

Sanders, J. O. (2017). Kepemimpinan

Rohani (F. S.S. (ed.); 2nd ed.).

Kalam Hidup.

Setiaman, A., Sugiana, D., \&

Mahameruaji, J. N. (2013).

Implementasi Kebijakan

Keterbukaan Informasi Publik.

Jurnal Kajian Komunikasi, 1(2),

196-205.

https://doi.org/10.24198/jkk.vol1n2.9

Setiawan, W. (2017). Era Digital dan

Tantangannya. Seminar Nasional

Pendidikan 2017, 1-9.

Tyas, D. L., Budiyanto, A. D., \& Santoso, A. J. (2016). Pengaruh Kekuatan Media Sosial dalam Pengembangan Kesenjangan Digital. Scientific Journal of Informatics, 2(2), 147. https://doi.org/10.15294/sji.v2i2.508 3

Waruwu, M. (2020). Implementasi Hubungan Baik terhadap Pemimpin dan Bawahan. In M. Oci (Ed.), Implikasi Pengajaran Teologi Praktika (1st ed., pp. 157-169). YPSIM. 
Weningtyas, E., \& Ni, M. (2012).

Pengaruh Komunikasi Interpersonal.

Psikologika, 17, 17-26.

Wiryomartono, B. (2020). Power,

Territoriality, and Society in

Indonesia: A Historical Overview.

Traditions and Transformations of

Habitation in Indonesia, 9-34.

https://doi.org/10.1007/978-981-15-

3405-8_2

Wisman, Y. (2017). Komunikasi Efektif

Dalam Dunia Pendidikan. Jurnal

Nomosleca, 3(2).

https://doi.org/10.26905/nomosleca.v

3i2.2039

Yudiaatmaja, F. (2013). Kepemimpinan:

Konsep; Teori dan Karakternya.

Media Komunikasi, 12(2), 29-38.

Zaluchu, S. E. (2020a). Strategi Penelitian

Kualitatif dan Kuantitatif Di Dalam

Penelitian Agama. Evangelikal:

Jurnal Teologi Injili Dan Pembinaan

Warga Jemaat, 4(1), 28-38.

https://doi.org/10.46445/ejti.v4i1.167

Zaluchu, S. E. (2020b). Riset 'Leadership

Understanding' Gembala-gembala

Peserta Lembaga Kajian Gereja

(LKG) Jawa Timur. BIA': Jurnal

Teologi Dan Pendidikan Kristen

Kontekstual, 3(1), 102-113.

https://doi.org/10.34307/b.v3i1.154 